\title{
Isparta Koșullarında Farklı Ekim Zamanı ve Bitki Sıklığının Șeker Mısırında (Zea mays saccharata Sturt.) Taze Koçan Ağırığı ve Bazı Tarımsal Özelliklere Etkisi
}

\author{
*ilknur AKGÜN, Yudum BURCU, Ruziye KARAMAN, Muharrem KAYA \\ Süleyman Demirel Üniversitesi Ziraat Fakültesi Tarla Bitkileri Bölümü, Isparta \\ *Sorumlu yazar e-posta (Corresponding author; e-mail): ilknurakgun@sdu.edu.tr
}

\begin{abstract}
Öz
Bu çalıșmada, farklı ekim zamanı ve bitki sıklığının Batem Tatlı șeker mısırında (Zea mays saccharata Sturt.) taze koçan verimi ve bazı tarımsal özellikler üzerine etkisinin belirlenmesi amaçlanmıștır. Araștırma, Tesadüf Bloklarında Bölünmüș Parseller Deneme planına uygun olarak üç tekerrürlü kurulmuștur. Ana parsellere ekim zamanı (15 Nisan, 1 Mayıs, 15 Mayıs, 1 Haziran ve 15 Haziran), alt parsellere ise sıra üzeri mesafeleri $(15,20,25 \mathrm{~cm})$ yerleștirilmiștir. Her parsele $20 \mathrm{~kg} / \mathrm{da}$ azot ve $10 \mathrm{~kg} / \mathrm{da}$ fosfor $\left(\mathrm{P}_{2} \mathrm{O}_{5}\right)$ hesabıyla gübre uygulanmıștır. Araștırma sonuçlarına göre; ekim zamanı ve sıra üzeri mesafenin kardeș sayısına, koçan uzunluğuna, kavuzsuz taze koçan ağırlığına, koçanda tane sayısına, tepe püskülü ve koçan püskülü çıkarma süresine etkisi istatistiksel olarak önemli bulunmuștur. Ayrıca, yılların etkisi koçan boyu hariç incelenen diğer özelliklerde önemli olmuștur. İncelenen birçok özellikte ekim zamanı ve sıra üzeri mesafe arasındaki interaksiyon önemli çıkmıștır. Sonuç olarak, taze koçan ağırlığı ve tane sayısı dikkate alındığında, Batem Tatı șeker mısırı çeșidi, Isparta koșullarında Mayıs ayının ilk haftasından Haziran ayının ilk haftasına kadar $15 \mathrm{~cm}$ sıra üzeri mesafede ekilebileceği belirlenmiștir.
\end{abstract}

Anahtar Kelimeler: Șeker mısırı, bitki sıklığı, ekim zamanı, taze koçan ağırlığı

The Effects of Plant Density and Different Sowing Dates on Fresh Ear Weight and Some Agricultural Characters of Sweet Corn (Zea mays saccharata Sturt.) Grown under Isparta Conditions

Abstract

The purpose of this study was to investigate the effects of plant density and different sowing dates on fresh ear weight and quality characters of Batem Tatli sweet corn cultivar. The trial was established as randomized block split-plot design with 3 replications. The different sowing dates (15 April, 1 May, 15 May, 1 June and 15 June) consisted the main plots whereas distances within rows were the sub-plots (15, $20,25 \mathrm{~cm}$ ). Phosphorus and nitrogen fertilizers were applied $10 \mathrm{~kg} / \mathrm{da}$ as $\mathrm{P}_{2} \mathrm{O}_{5}$ and $20 \mathrm{~kg} / \mathrm{da}$ as $\mathrm{N}$ to the pilots. Results showed that the effect of sowing time and distances within rows had significant effect on number of tiller, ear length, husked fresh ear weight, seed number in ear, days to tasseling and days to silking. However, year had a significant effect on examined characters except to ear length. The interaction between sowing time and distance in the row was found significant. As a result, when the fresh ear weight and seed number in ear was taken into consideration, it was found that in Isparta conditions, Batem Tatli sweet corn cultivar should be sown between first week of May and first week of June with more than 15 $\mathrm{cm}$ raw spacing.

Keywords: Sweet corn, plant density, sowing date, fresh ear weight

Giriș

W $\begin{aligned} & \text { ssır, besin maddesi yönünden } \\ & \text { zengin olması nedeniyle insan }\end{aligned}$ ve hayvan beslenmesinde, farklı kullanım alanlarından dolayı da sanayide önemli yere sahip ürünlerden biridir. Tatlı mısır, ülkemize 1930’lu yıllarda girmiș olmasına rağmen, șeker mısırının ekim alanı ve üretim miktarı ile ilgili istatistiksel kayıtlar tespit edilememiștir. Șeker mısırın Peruluların "Chuspillo ya da "Chullpi" dedikleri mısır çeșidinden mutasyonla oluștuğu ileri sürülmektedir (Azanza ve ark. 1996). Șeker mısırı süt olum döneminde hasat 
edildiğinden dolayı tanelerinin besin değerleri oldukça yüksektir. Şeker mısırının tanesinde, orta seviyede protein, vitamin A ve potasyum bulunduğu bildirilmiștir (Dickerson 1996). Yine șeker mısırı embriyosunun diğer mısır varyetelerine göre daha büyük olmasından dolayı, yağ ve protein oranının daha fazla olduğu ileri sürülmektedir (Sade 2002).

Bu bilgilerden de anlașıldığı gibi, besin değeri yüksek olan șeker mısırı, dünyada ve ülkemizde taze tüketiminin (kaynatılarak ve közlenerek doğrudan) yanında, konserve, dondurulmuș ürün ya da kavurga gibi farklı șekillerde kullanılmak üzere yetiștiriciliği yapılmaktadır. Ayrıca, șeker mısırı taze olarak tüketildiğinden, arta kalan yeșil bitkiler doğrudan veya silaj șeklinde hayvan yemi olarak da kullanılabilir.

Șeker mısırı üzerinde yapılan çalıșmalar incelendiğinde ekim zamanı ve bitki sıklığının verim ve kalite üzerine etkili olduğu bildirilmiștir (Uçkesen 2000; Turgut ve Balcı 2002; Kahrıman ve ark. 2007; Atakul 2011). $\mathrm{Bu}$ nedenle birim alandan yüksek gelir elde etmek için o bölgenin iklim koșullarına uygun çeșitlerin belirlenmesi ve en uygun zamanda ekilmesi önemlidir.

Son yıllarda tüketimi hızla artan șeker mısırında sürekli yeni çeșitleri piyasaya sunulmaktadır. Bu çeșitlerin tanıtılması ve yöreye alternatif ürün imkânı sunulması üreticilere ekonomik katkı sağlayacağı düșünülmektedir. Özellikle șeker oranı arttırılmıș mısır çeșitlerinde, düșük toprak sıcaklığında zayıf çimlenme ve yavaș büyüme gibi sorunlar bulunmaktadır (Dickerson 1996). $\mathrm{Bu}$ nedenle yeni geliștirilen bu çeșitlerde birim alandan yüksek verim alınabilmesi için, çeșitlerin yöreye adaptasyonu ve yetiștirme tekniklerinin belirlenmesi gerekmektedir.

Bu çalıșmada, Isparta koșullarında farklı ekim zamanı ve bitki sıklığının Batem Tatı șeker mısırı çeșidinin taze koçan ağırlığı ve bazı tarımsal özellikler üzerine etkisinin belirlenmesi, yöreye tanıtılması, uygun ekim zamanı ve ekim sıklığının üreticilere önerilmesi amaçlanmıștır.

\section{Materyal ve Yöntem}

$\mathrm{Bu}$ araștırma, Süleyman Demirel Üniversitesi Ziraat Fakültesi Araștırma ve
Deneme Uygulama Arazisi'nde 2015 ve 2016 yıllarında yürütülmüștür. Çalıșmada BATEM Tatlı șeker mısır çeșidi kullanılmıș ve tüm parsellere $20 \mathrm{~kg} / \mathrm{da}$ azot ve $10 \mathrm{~kg} / \mathrm{da}$ fosfor $\left(\mathrm{P}_{2} \mathrm{O}_{5}\right)$ uygulanmıștır. Azotlu gübrenin yarısı ekimle birlikte amonyum sülfat formunda, diğer yarısı ise boğaz doldurma devresinde $(40-50 \mathrm{~cm})$ amonyum nitrat formunda, fosforlu gübrenin tamamı ise ekimle birlikte triple süper fosfat gübresi kullanılarak verilmiștir.

Araștırma, tesadüf bloklarında bölünmüș parseller deneme desenine göre üç tekrarlamalı olarak yürütülmüș ve ana parsellerde ekim zamanı (15 Nisan, 1 Mayıs, 15 Mayıs, 1 Haziran, 15 Haziran), alt parsellerde ise ekim sıklığı (15 $\mathrm{cm}, 20 \mathrm{~cm}, 25 \mathrm{~cm}$ ) yer almıștır. Parsel alanı 11.2 $\mathrm{m}^{2}(4 \mathrm{~m} \times 4$ sıra, sıra arası $70 \mathrm{~cm})$ olmuștur. Beș ekim tarihinde tohumlar markörle açılan sıralara belirtilen sıra üzeri mesafelerde elle açılan ocaklara ekilmiștir. Her ocağa iki tohum atılmıștır. Çimlenme tamamlandıktan sonra elle yapılan çapalama ișlemleri ile hem yabancı ot mücadelesi, hem de her ocakta 1 bitki bırakılmıștır. Haziran ekimlerinde çimlenme sağlayabilmek için yağmurlama sistemi ile tüm deneme sulanmıștır. Diğer sulamalar bitkinin nem stresine girmesini önleyecek șekilde damla sulama yöntemiyle uygulanmıștır. Farklı ekim tarihlerinde yetiștirilen bitkiler süt olum döneminde hasat edilmiștir.

Araștırmada kardeș sayısı, tepe püskülü ve koçan püskülü çıkarma süresi, kavuzsuz taze koçan ağırlığı (g), koçanda tane sayısı ve koçan boyu incelenmiștir. Verilerin varyans analizleri Totemstat istatistik paket programından faydalanılarak yapılmıș ve ortalamalar arasındaki farklılıklar LSD testine göre belirlenmiștir.

Denemenin kurulduğu alanın toprakları tınlı, hafif alkali $(\mathrm{pH}=7.9)$ ve organik madde açısından yetersiz, fosfor bakımından orta seviyede, potasyum bakımından ise zengindir.

Araștırma yürütüldüğü (2015 ve 2016) ve uzun yıllar (1970-2014) ortalamasına ait sıcaklık değerleri incelendiğinde, birinci yılda nisan ayında sıcaklık değerleri uzun yıllar ortalamasının altında gerçekleșmiș $\left(9.2^{\circ} \mathrm{C}\right.$ uzun yillar ort. $14.5^{\circ} \mathrm{C}$ ) ve 23 Nisanda kar yağıșı meydana gelmiștir. Bu durum 15 Nisan ekimlerinde toprak sıcaklı̆ııın düșük olmasına 
ve çimlenmede gecikmelere neden olmuștur. Ortalama sıcaklık değerleri ise 1 . yılda $\left(16.7^{\circ} \mathrm{C}\right)$ uzun yıllar ortalamasına $\left(16.8^{\circ} \mathrm{C}\right)$ benzer, 2. yılda $\left(18.4^{\circ} \mathrm{C}\right)$ ise daha yüksek olmuștur (Anonim, 2015; 2016). Denemenin yürütüldüğü yıllarda vejetasyon dönemindeki toplam yağıș miktarı uzun yıllar ortalamasından daha fazladır (toplam yağıș 1. yıl $344.6 \mathrm{~mm}$; 2. yıl $310.4 \mathrm{~mm}$; uzun yıllar, $268.5 \mathrm{~mm}$ ).

\section{Bulgular ve Tartıșma}

\section{Kardeș Sayısı}

Araștırmada kardeș sayısı üzerine yılların, ekim zamanının ve sıra üzeri mesafenin etkisi istatistiksel olarak önemli bulunmuștur (Çizelge 1). Batem Tatlı șeker mıııının kardeșlenme yeteneği yıllara göre, 1. yıl 1.95 adet, 2. yıl 2.80 adet; ekim zamanlarına göre 2.01-2.77 adet; sıra üzeri mesafeye göre 2.28-2.47 adet arasında değișmiștir (Çizelge 1).

İki yıllık ortalamalara göre haziran ayında yapılan ekimlerde kardeș sayısı artmıștır. Ekim zamanı $x$ sıra üzeri mesafe interaksiyonu incelendiğinde, ilk ekim tarihi olan 15 Nisan tarihinde sıra üzeri mesafe kardeș sayısına önemli seviyede etkide bulunmaz iken, diğer ekim tarihlerinde farklı bitki yoğunluğunda elde edilen kardeș sayıları önemli seviyede farklı bulunmuștur. Genel olarak $15 \mathrm{~cm}$ sıra üzeri mesafede kardeș sayısı azalmıștır. Bu durum bitki sıklığı arttıkça besin elementi rekabetinin artması ile açıklanabilir. Ayrıca sıcaklık artıșı da kardeșlenmeyi teșvik etmiștir. Șeker mısırı taze olarak tüketildiğinde dolayı, kardeșlenme arta kalan yeșil bitkilerin farklı șekillerde (kaba yem veya silaj) kullanılabilir olması yönüyle önemli olabilir. Diğer taraftan olușan kardeșlerde gelișen koçanların ticari bir değeri yoktur. Ancak kardeșlerin koparılmasının koçan boyunun azalmasına neden olduğu bildirilmiștir (Park ve ark. 1989; Hanna ve Story 1992). Yine kardeșlerin uzaklaștırımasının koçan püskülü çıkarma süresini kısalttığı bildirilmiștir (Sharma ve Adamu 1984). Bu durum, yaprak yoğunluğunun azalmasına bağlı olarak fotosentetik etkinliğin azalması ve vejetatif periyodun kısalması ile açıklanabilir. Araștırmada haziran ayında yapılan ekimlerde kardeșlenme kapasitesinin artmıș olması sıcaklığa bağlı olarak bitkinin foto-sentetik etkinliğini arttırma eğilimi olarak düșünülebilir.

\section{Tepe Püskülü Çıkarma Süresi}

Araștırmada tepe püskülü çıkarma süresi ekim tarihlerine göre önemli değișiklik göstermiș ve ortalama en kısa süre 15 Haziran (62.3 gün), en uzun ise 90.8 gün ile 15 Nisan ekiminde elde edilmiștir. Yine birim alandaki bitki sıklığının artması tepe püskülü çıkartma süresini kısaltmıș ve $15 \mathrm{~cm}$ sıra üzeri mesafede 71.8 gün iken, $25 \mathrm{~cm}$ de 75.1 güne çıkmıștır (Çizelge 2). Tüm ekim zamanlarında

Çizelge 1. Șeker mısııında farklı ekim zamanları ve sıra üzeri mesafelerde kardeș sayısı (adet)

Table 1. Number of tiller at different sowing dates and distances within rows in sweet corn

\begin{tabular}{|c|c|c|c|c|c|c|c|}
\hline \multirow{2}{*}{ Yıl } & \multirow{2}{*}{$\begin{array}{c}\text { Sıra Üzeri } \\
\text { Mesafe }(\mathrm{cm})\end{array}$} & \multicolumn{6}{|c|}{ Ekim Zamanları } \\
\hline & & 15 Nisan & 1 Mayıs & 15 Mayıs & 1 Haziran & 15 Haziran & Ortalama \\
\hline \multirow{4}{*}{1} & $15 \mathrm{~cm}$ & 2.12 & 1.58 & 1.19 & 2.32 & 1.66 & 1.77 \\
\hline & $20 \mathrm{~cm}$ & 2.16 & 1.93 & 1.70 & 2.26 & 2.49 & 2.11 \\
\hline & $25 \mathrm{~cm}$ & 2.10 & 1.93 & 1.55 & 2.08 & 2.17 & 1.97 \\
\hline & Ortalama & 2.13 & 1.81 & 1.48 & 2.22 & 2.10 & 1.95 \\
\hline \multirow{4}{*}{2} & $15 \mathrm{~cm}$ & 2.23 & 2.45 & 2.46 & 3.46 & 3.36 & 2.80 \\
\hline & $20 \mathrm{~cm}$ & 2.43 & 2.50 & 2.50 & 3.36 & 3.40 & 2.84 \\
\hline & $25 \mathrm{~cm}$ & 2.10 & 2.64 & 2.63 & 3.13 & 3.30 & 2.76 \\
\hline & Ortalama & 2.25 & 2.53 & 2.53 & 3.32 & 3.35 & 2.80 \\
\hline \multirow{4}{*}{ 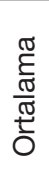 } & $15 \mathrm{~cm}$ & $2.17 \mathrm{a}$ & $2.02 \mathrm{~b}$ & $1.82 \mathrm{~b}$ & $2.89 \mathrm{a}$ & $2.51 \mathrm{~b}$ & 2.28 \\
\hline & $20 \mathrm{~cm}$ & $2.30 \mathrm{a}$ & $2.21 \mathrm{ab}$ & $2.10 \mathrm{a}$ & $2.82 \mathrm{ab}$ & $2.94 \mathrm{a}$ & 2.47 \\
\hline & $25 \mathrm{~cm}$ & $2.10 \mathrm{a}$ & $2.28 \mathrm{a}$ & $2.09 \mathrm{a}$ & $2.60 \mathrm{~b}$ & $2.73 a b$ & 2.36 \\
\hline & Ortalama & 2.19 & 2.17 & 2.01 & 2.77 & 2.73 & \\
\hline
\end{tabular}

YII $(Y)=242.312^{\star *}$; Ekim zamanı $(E K)=33.208^{\star *}$; Sıra Üzeri Mesafe $(S U ̈ M)=4.086^{*} ;$ YxEK=13.523**; YxSÜM=4.891*; EKxSÜM=2.981*; $Y x E K x S U ̈ M=1.502^{\text {ns }}$

*Aynı sütunda aynı harfle verilen ortalamalar arasındaki fark önemli değildir. 
Çizelge 2. Șeker mısırında farklı ekim zamanları ve sıra üzeri mesafelerde tepe püskülü çıkarma süresi (gün)

Table 2. Days to tasseling at different sowing dates and distances within rows in sweet corn

\begin{tabular}{|c|c|c|c|c|c|c|c|}
\hline \multirow{2}{*}{ YIl } & \multirow{2}{*}{$\begin{array}{c}\text { Sıra Üzeri } \\
\text { Mesafe }(\mathrm{cm})\end{array}$} & \multicolumn{6}{|c|}{ Ekim Zamanları } \\
\hline & & 15 Nisan & 1 Mayıs & 15 Mayıs & 1 Haziran & 15 Haziran & Ortalama \\
\hline \multirow{4}{*}{1} & $15 \mathrm{~cm}$ & 86.0 & 78.0 & 75.0 & 66.0 & 62.7 & 73.5 \\
\hline & $20 \mathrm{~cm}$ & 94.0 & 80.0 & 71.0 & 63.0 & 62.7 & 74.1 \\
\hline & $25 \mathrm{~cm}$ & 96.0 & 80.0 & 73.0 & 66.0 & 62.7 & 75.5 \\
\hline & Ortalama & 92.0 & 79.3 & 73.0 & 65.0 & 62.7 & 74.4 \\
\hline \multirow{4}{*}{2} & $15 \mathrm{~cm}$ & 85.0 & 76.0 & 65.0 & 64.3 & 60.0 & 70.1 \\
\hline & $20 \mathrm{~cm}$ & 90.0 & 80.0 & 71.0 & 64.7 & 63.0 & 73.7 \\
\hline & $25 \mathrm{~cm}$ & 94.0 & 80.0 & 71.0 & 65.0 & 63.0 & 74.6 \\
\hline & Ortalama & 89.7 & 78.7 & 69.0 & 64.7 & 62.0 & 72.8 \\
\hline \multirow{4}{*}{$\begin{array}{l}\frac{\pi}{\mathbb{\sigma}} \\
\frac{\pi}{\pi} \\
\frac{\pi}{ \pm}\end{array}$} & $15 \mathrm{~cm}$ & $85.5 \mathrm{c}$ & $77.0 \mathrm{~b}$ & $70.0 \mathrm{c}$ & $65.2 \mathrm{~b}$ & $61.3 b$ & 71.8 \\
\hline & $20 \mathrm{~cm}$ & $92.0 \mathrm{~b}$ & $80.0 \mathrm{a}$ & $71.0 \mathrm{~b}$ & $63.8 \mathrm{c}$ & $62.8 \mathrm{a}$ & 73.9 \\
\hline & $25 \mathrm{~cm}$ & $95.0 \mathrm{a}$ & $80.0 \mathrm{a}$ & $72.0 \mathrm{a}$ & $65.5 \mathrm{a}$ & $62.8 \mathrm{a}$ & 75.1 \\
\hline & Ortalama & 90.8 & 79.0 & 71.0 & 64.8 & 62.3 & \\
\hline
\end{tabular}

YIl $(Y)=432.000^{\star \star} ;$ Ekim zamanı $(E K)=18113.625^{\star \star} ;$ Sıra Üzeri Mesafe $(S U ̈ M)=619.000^{\star *} ; Y x E K=81.375^{\star *} ; Y x S U ̈ M=302.000^{\star \star} ;$ EKxSÜM $=345.500^{\star *} ;$ YxEKxSÜM $=137.000^{\star \star}$

*Aynı sütunda aynı harfle verilen ortalamalar arasındaki fark önemli değildir.

birim alandaki bitki sıklı̆ının azalması bitkilerin generatif döneme geçiș süresini uzatmıștır. Bu durum, bitki besin elementi ve ıșık yönünden rekabetin daha az olmasından kaynaklanmaktadır. Tepe püskülü çıkarma süresine çeșidin ve ekim zamanının önemli etkisinin olduğu, nemli ve serin havalarda tepe püskülü çıkarma süresinin uzadığı, sıcaklık artıșına bağlı olarak tepe püskülü çıkarma süresinin kısaldığı bildirilmiștir (Cesurer ve Ülger 1997; Sönmez ve ark. 2013). Bu sonuçlar bizim elde ettiğimiz sonuçlarla benzerlik göstermekle birlikte tepe püskülü çıkarma süresi üzerine genotipin yanında tarımsal uygulamaların da etkili olduğunu açıklamıștır. Özellikle șeker mısırı taze tüketim amacıyla kullanıldığından dolayı, turfanda olarak pazara sunulmasında tepe püskülü çıkarma süresi erkencilik açısından önemlidir.

\section{Koçan Püskülü Çıkarma Süresi}

Batem Tatı ı̧eșidinde ekim zamanına göre koçan püskülü çıkarma süresi, tepe püskülü çıkarma süresine benzer olmuș ancak koçan püskülü çıkarma süresi daha uzun sürmüștür. Koçan püskülü çıkarma süresi üzerine yılların, ekim zamanının ve sıra üzeri mesafesinin etkisi önemli bulunmuștur. Araștırmada ekim zamanlarına göre ortalama koçan püskülü çıkarma süresi 64.33-95.5 gün, sıra üzeri mesafeye göre ise 77.4-78.3 gün arasında değișmiștir. En uzun süre 15 Nisan, en kısa ise 15 Haziran ekimlerinde belirlenmiștir. Sıcaklık artıșı koçan püskülü çıkarma süresini kısaltmıștır. Farklı ekim zamanlarında sıra üzeri mesafenin koçan püskülü çıkarma üzerine etkisi farklı bulunmuștur. Genel ortalama olarak birim alandaki bitki sıklığı hem fazla $(15 \mathrm{~cm})$ hem de az $(25 \mathrm{~cm})$ olduğunda koçan püskülü çıkarma süresi 1-2 gün uzun olmuștur (Çizelge 3).

Sonuç olarak birim alanda bitki sayısının artması bitkilerin strese girmesine neden olmuș (ıșık, besin elementi sıcaklık vb.), birim alandaki bitki sayısının azalması da rekabeti azalttığı için koçan olușumunu geciktirmiștir. Sencar (1998) bitki sıklığı arttıkça bitkilerin ıșıklanma rekabetinin arttığı ve vejetatif gelișme döneminin uzadığını bildirmiștir. Taș (2010) mısırda çiçeklenme süreleri üzerine genotip etkili olsa da çevre șartlarından, özellikle de sıcaklık tarafından etkilendiğini bildirmiștir.

\section{Koçan Uzunluğu}

Araștırmada koçan boyu üzerine yılların önemli bir etkisi belirlenmemiștir. Ancak ekim zamanı ve sıra üzeri mesafenin etkisi önemli bulunmuștur (Çizelge 4). İki yillık ortalamalara göre en uzun koçan boyu $19.18 \mathrm{~cm}$ ile 15 Mayıs tarihinde yapılan ekimde, en kısa $(16.12 \mathrm{~cm})$ ise 15 Nisan tarihinde ekilen bitkilerde belirlenmiștir. 
Çizelge 3. Șeker mısıında farklı ekim zamanları ve sıra üzeri mesafelerde koçan püskülü çıkarma süresi (gün)

Table 3. Days to silking at different sowing dates and distances within rows in sweet corn

\begin{tabular}{|c|c|c|c|c|c|c|c|}
\hline \multirow{2}{*}{ YIl } & \multirow{2}{*}{$\begin{array}{c}\text { Sıra Üzeri Mesafe } \\
(\mathrm{cm})\end{array}$} & \multicolumn{6}{|c|}{ Ekim Zamanları } \\
\hline & & 15 Nisan & 1 Mayıs & 15 Mayıs & 1 Haziran & 15 Haziran & Ortalama \\
\hline \multirow{4}{*}{1} & $15 \mathrm{~cm}$ & 97.0 & 86.0 & 79.0 & 68.0 & 65.3 & 79.1 \\
\hline & $20 \mathrm{~cm}$ & 98.0 & 85.0 & 73.0 & 65.0 & 65.3 & 77.3 \\
\hline & $25 \mathrm{~cm}$ & 93.0 & 87.0 & 75.0 & 68.0 & 65.3 & 77.7 \\
\hline & Ortalama & 96.0 & 86.0 & 75.7 & 67.0 & 65.3 & 78.0 \\
\hline \multirow{4}{*}{2} & $15 \mathrm{~cm}$ & 93.0 & 84.0 & 79.0 & 69.0 & 63.0 & 77.6 \\
\hline & $20 \mathrm{~cm}$ & 96.0 & 86.0 & 73.0 & 70.0 & 63.0 & 77.6 \\
\hline & $25 \mathrm{~cm}$ & 96.0 & 87.0 & 75.0 & 70.0 & 64.0 & 78.4 \\
\hline & Ortalama & 95.0 & 85.7 & 75.7 & 69.7 & 63.3 & 77.9 \\
\hline \multirow{4}{*}{$\begin{array}{l}\frac{\mathbb{\sigma}}{E} \\
\frac{\pi}{\sigma} \\
\frac{\pi}{\widetilde{T}} \\
\stackrel{0}{0}\end{array}$} & $15 \mathrm{~cm}$ & $95.0 \mathrm{~b}$ & $85.0 \mathrm{c}$ & $79.0 \mathrm{a}$ & $68.5 \mathrm{~b}$ & $64.2 \mathrm{a}$ & 78.3 \\
\hline & $20 \mathrm{~cm}$ & $97.0 \mathrm{a}$ & 85.5 b & $73.0 \mathrm{c}$ & $67.5 \mathrm{c}$ & $64.2 \mathrm{a}$ & 77.4 \\
\hline & $25 \mathrm{~cm}$ & $94.5 \mathrm{c}$ & $87.0 \mathrm{a}$ & $75.0 \mathrm{~b}$ & $69.0 \mathrm{a}$ & $64.7 \mathrm{a}$ & 78.0 \\
\hline & Ortalama & 95.5 & 85.83 & 75.66 & 68.33 & 64.33 & \\
\hline
\end{tabular}

YII $(Y)=12.000^{* *}$; Ekim zamanı $(E K)=88189.500^{* *}$; Sıra Üzeri Mesafe $(S U ̈ M)=189.000^{\star *}$; YxEK= 409.500**; YxSÜM= 309.000*; EKxSÜM $=530.250^{\star *} ;$ YxEKxSÜM $=147.750^{\star \star}$

*Aynı sütunda aynı harfle verilen ortalamalar arasındaki fark önemli değildir.

Bitki sıklığının artması koçan boyunu olumsuz etkilemiș, en kısa koçan boyu $15 \mathrm{~cm}$ sıra üzeri ekimlerde belirlenmiștir. Diğer taraftan mayıs ayı içerisinde yapılan ekimlerde koçan boyu üzerine sıra üzeri mesafesinin etkisi önemli bulunmamıș, istatistiksel olarak aynı grupta yer almıștır. Diğer ekim tarihlerinde $25 \mathrm{~cm}$ sıra üzeri mesafede koçan uzunluğu daha fazla olmuștur.

Mısırda koçan uzunluğu en fazla değișkenlik gösteren özelliklerden birisi olup (Deng ve ark.
2009), ekim zaman, çeșit ve bitki sıklığının koçan uzunluğu üzerine etkisi farklı bölgelerde değișik araștırıcılar tarafından incelenmiștir. Turgut (2000) șeker mısıında yaptığı çalıșmada, farklı sıra üzeri mesafelerinin $(10,15,20,25,30$ ve 35 $\mathrm{cm})$ koçan boyuna önemli etkisinin olduğunu bildirmiștir. Araștırma sonucunda 20-35 cm sıra üzeri mesafede istatistiki farkın olmadığını, ancak koçan boyunun arttığını tespit etmiștir. Alıcı (2005) tarafından yapılan çalıșmada ekim sıklığı azaldıkça koçan boyunun arttığını ve en

Çizelge 4. Șeker mısırında farklı ekim zamanları ve sıra üzeri mesafelerde koçan uzunluğu (cm) Table 4. Ear length (cm) at different sowing dates and distances within rows in sweet corn

\begin{tabular}{|c|c|c|c|c|c|c|c|}
\hline \multirow{2}{*}{ YIl } & \multirow{2}{*}{$\begin{array}{l}\text { Sıra Üzeri Mesafe } \\
(\mathrm{cm})\end{array}$} & \multicolumn{6}{|c|}{ Ekim Zamanları } \\
\hline & & 15 Nisan & 1 Mayıs & 15 Mayıs & 1 Haziran & 15 Haziran & Ortalama \\
\hline \multirow{4}{*}{1} & $15 \mathrm{~cm}$ & 16.10 & 18.84 & 18.64 & 18.65 & 16.55 & 17.76 \\
\hline & $20 \mathrm{~cm}$ & 16.99 & 17.77 & 19.25 & 18.86 & 18.38 & 18.25 \\
\hline & $25 \mathrm{~cm}$ & 17.70 & 19.52 & 18.42 & 19.08 & 18.91 & 18.73 \\
\hline & Ortalama & 16.93 & 18.71 & 18.77 & 18.86 & 17.95 & 18.25 \\
\hline \multirow{4}{*}{2} & $15 \mathrm{~cm}$ & 13.02 & 18.66 & 19.63 & 18.41 & 17.66 & 17.48 \\
\hline & $20 \mathrm{~cm}$ & 16.46 & 19.61 & 19.52 & 19.26 & 17.94 & 18.56 \\
\hline & $25 \mathrm{~cm}$ & 16.47 & 18.89 & 19.59 & 19.41 & 19.92 & 18.86 \\
\hline & Ortalama & 15.31 & 19.06 & 19.58 & 19.03 & 18.50 & 18.30 \\
\hline \multirow{4}{*}{ 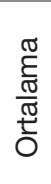 } & $15 \mathrm{~cm}$ & $14.56 \mathrm{~b}$ & $18.75 \mathrm{a}$ & $19.14 \mathrm{a}$ & $18.53 b$ & $17.10 \mathrm{c}$ & 17.62 \\
\hline & $20 \mathrm{~cm}$ & $16.72 \mathrm{a}$ & $18.70 \mathrm{a}$ & $19.38 \mathrm{a}$ & $19.06 \mathrm{ab}$ & $18.16 \mathrm{~b}$ & 18.40 \\
\hline & $25 \mathrm{~cm}$ & $17.09 \mathrm{a}$ & $19.20 \mathrm{a}$ & $19.00 \mathrm{a}$ & $19.25 \mathrm{a}$ & $19.42 \mathrm{a}$ & 1879 \\
\hline & Ortalama & 16.12 & 18.88 & 19.18 & 18.94 & 18.22 & \\
\hline
\end{tabular}

Yıl $(Y)=0.189 n s ;$ Ekim zamanı $(E K)=86.781^{\star *}$; Sıra Üzeri Mesafe $(S U ̈ M)=11.665^{\star *} ; Y x E K=12.772^{\star \star} ; Y x S U ̈ M=16.175^{\star \star} ; E K x S U ̈ M=$ $11.700^{\star *}$; YxEKxSÜM $=4.559^{\star \star}$

*Aynı sütunda aynı harfle verilen ortalamalar arasındaki fark önemli değildir. 
yüksek değerin $24 \mathrm{~cm}$ sıra üzeri mesafede elde edildiğini bildirmiștir. Atakul (2011) tarafından yapılan çalıșmada farkı ekim tarihlerinin koçan uzunluğu üzerine önemli bir etkisinin olduğunu bildirmiștir.

\section{Koçanda Tane Sayısı}

Araștırmada koçanda tane sayısı yıllara göre önemli farklılık göstermiș ve 1. yıl (489.99 adet) 2. yıldan (464.06 adet) daha fazla koçanda tane sayısı elde edilmiștir (Çizelge 5). İki yıllık ortalama veriler incelendiğinde, koçanda tane sayısı ekim zamanlarına göre 423.52-531.04 adet, sıra üzeri mesafeye göre 454.34-497.57 adet arasında değișmiștir. Erken tarihte (15 Nisan) ve haziran ayı içerisinde yapılan ekimlerde koçanda tane sayısı azalmıștır. Yine bitki sıklığının fazla olduğu $15 \mathrm{~cm}$ sıra üzeri mesafede ortalama koçanda tane sayısı düșük bulunmuștur. Birim alandaki bitki sıklığının azalmasına bağlı olarak koçanda tane sayısı da artmıștır. Ekim zamanı $x$ sıra üzeri mesafesi interaksiyonu önemli bulunmuș ve 15 Nisan, 1 Mayıs ve 1 Haziran ekim tarihlerinde koçanda tane sayısı yönünden sayısal olarak farklı değerler elde edilmiș olsa da bu farklılık önemli olmamıștır (Çizelge 5).

Mısır bitkisinde koçandaki tane sayısı genellikle genetik yapının kontrolünde (Kırtok 1998) olsa da, çevre șartları döllenme üzerinde etkili olabilmektedir. Nitekim Turgut (2000), koçanda tane sayısının $30 \mathrm{~cm}$ sıra üzeri mesafesine kadar artıș gösterdiğini, ekim sıklığı arttıkça koçan çapının ve koçan boyunun düșmesi nedeniyle koçanda tane sayısının da azaldığını bildirmiștir. Alan ve ark. (2011) ekim zamanının șeker mısııında koçanda tane sayısını önemli seviyede etkilediğini, erken yapılan ekimde (1 Mayıs) tane sayısın azaldığını ortaya koymuștur.

Araștırmada ekimin erken ya da haziran ayında yapılması durumunda koçandaki tane sayısının azalmasında koçan boyunun azalması yanında sıcaklık faktörünün de döllenmede sorun olabileceği düșünülmektedir. Çünkü 1 Mayıs ve 1 Haziran tarihlerinde elde edilen koçan boyları birbirine yakın iken, tane sayıları önemli seviyede farklı bulunmuștur.

\section{Kavuzsuz Taze Koçan Ağırığı}

Kavuzsuz taze koçan ağırlığı yıllara göre önemli değișiklik göstermiș ve ikinci yıl verileri daha yüksek bulunmuș olup, bu farklılık önemli olmuștur (Çizelge 6). Araștırmada kavuzsuz taze koçan ağırlığına ekim zamanı ve sıra üzeri mesafenin etkisi de önemli bulunmuștur. İki yıllık ortalamalara göre en yüksek taze koçan ağırlığı 15 Mayıs tarihinde belirlenmiș (235.06 g), ancak 1 Haziran tarihinde elde edilen değer $(233.33 \mathrm{~g})$ arasında önemli bir farklılık belirlenmemiștir. En düșük değer, ekim 15 Nisan'da yapıldığında (185.90 g) elde edilmiștir.

Çizelge 5. Șeker mısıında farklı ekim zamanları ve sıra üzeri mesafelerde koçanda tane sayısı (adet) Table 5. Seed number in ear at different sowing dates and distances within rows in sweet corn

\begin{tabular}{|c|c|c|c|c|c|c|c|}
\hline \multirow{2}{*}{ Yıl } & \multirow{2}{*}{$\begin{array}{c}\text { Sira Üzeri } \\
\text { Mesafe }(\mathrm{cm})\end{array}$} & \multicolumn{6}{|c|}{ Ekim Zamanları } \\
\hline & & 15 Nisan & 1 Mayıs & 15 Mayıs & 1 Haziran & 15 Haziran & Ortalama \\
\hline \multirow{4}{*}{1} & $15 \mathrm{~cm}$ & 475.09 & 555.40 & 496.52 & 505.52 & 397.26 & 485.95 \\
\hline & $20 \mathrm{~cm}$ & 474.93 & 557.68 & 475.85 & 480.57 & 472.54 & 492.31 \\
\hline & $25 \mathrm{~cm}$ & 442.05 & 546.30 & 494.58 & 479.68 & 495.80 & 491.68 \\
\hline & Ortalama & 464.02 & 553.128 & 488.98 & 488.59 & 455.20 & 489.99 \\
\hline \multirow{4}{*}{2} & $15 \mathrm{~cm}$ & 340.98 & 484.19 & 548.96 & 394.57 & 344.91 & 422.72 \\
\hline & $20 \mathrm{~cm}$ & 393.71 & 495.94 & 522.14 & 457.72 & 460.58 & 466.02 \\
\hline & $25 \mathrm{~cm}$ & 414.36 & 546.75 & 613.16 & 450.91 & 492.11 & 503.46 \\
\hline & Ortalama & 383.02 & 508.96 & 561.42 & 434.40 & 432.53 & 464.06 \\
\hline \multirow{4}{*}{$\begin{array}{l}\frac{\mathbb{\sigma}}{E} \\
\frac{\pi}{\pi} \\
\frac{\pi}{ \pm}\end{array}$} & $15 \mathrm{~cm}$ & $408.03 a$ & $519.79 a$ & $522.74 a b$ & $450.04 \mathrm{a}$ & $371.08 \mathrm{~b}$ & 454.34 \\
\hline & $20 \mathrm{~cm}$ & $434.32 \mathrm{a}$ & $526.81 \mathrm{a}$ & 498.99 b & $469.14 \mathrm{a}$ & $466.56 \mathrm{a}$ & 479.17 \\
\hline & $25 \mathrm{~cm}$ & $428.21 \mathrm{a}$ & $546.53 \mathrm{a}$ & $553.87 \mathrm{a}$ & $465.30 \mathrm{a}$ & $493.96 \mathrm{a}$ & 497.57 \\
\hline & Ortalama & 423.52 & 531.04 & 525.20 & 461.49 & 443.87 & \\
\hline
\end{tabular}

YIl $(Y)=8.828^{\star \star}$; Ekim zamanı $(E K)=24.822^{\star *}$; Sıra Üzeri Mesafe $(S U ̈ M)=8.249^{\star *} ; Y x E K=9.104^{\star *} ; Y x S U ̈ M=6.787^{\star \star} ; E K x S U ̈ M=2.940^{\star}$; YxEKxSÜM=0.488ns

*Aynı sütunda aynı harfle verilen ortalamalar arasındaki fark önemli değildir. 
Çizelge 6. Șeker mısırında farklı ekim zamanları ve sıra üzeri mesafelerde kavuzsuz koçan ağırlığı (g)

Table 6. Husked fresh ear weight $(g)$ at different sowing dates and distances within rows in sweet corn

\begin{tabular}{|c|c|c|c|c|c|c|c|}
\hline \multirow[b]{2}{*}{ Yıl } & \multirow{2}{*}{$\begin{array}{c}\text { Sira Üzeri } \\
\text { Mesafe }(\mathrm{cm})\end{array}$} & \multicolumn{6}{|c|}{ Ekim Zamanları } \\
\hline & & 15 Nisan & 1 Mayıs & 15 Mayıs & 1 Haziran & 15 Haziran & Ortala. \\
\hline \multirow{4}{*}{1} & $15 \mathrm{~cm}$ & 156.34 & 182.36 & 176.59 & 192.78 & 143.88 & $170.39 a$ \\
\hline & $20 \mathrm{~cm}$ & 158.36 & 160.47 & 167.92 & 161.33 & 157.83 & 161.18 \\
\hline & $25 \mathrm{~cm}$ & 153.12 & 160.86 & 165.14 & 175.44 & 162.00 & 163.31 \\
\hline & Ortalama & 155.94 & 167.89 & 169.88 & 176.52 & 154.57 & 164.96 \\
\hline \multirow{4}{*}{2} & $15 \mathrm{~cm}$ & 185.30 & 242.38 & 279.09 & 262.66 & 247.55 & 243.40 \\
\hline & $20 \mathrm{~cm}$ & 226.04 & 287.78 & 311.26 & 295.87 & 260.38 & 276.27 \\
\hline & $25 \mathrm{~cm}$ & 236.20 & 289.07 & 310.33 & 311.86 & 278.28 & 285.15 \\
\hline & Ortalama & 215.85 & 273.08 & 300.23 & 290.13 & 262.07 & 268.27 \\
\hline \multirow{4}{*}{$\begin{array}{l}\frac{\mathbb{\pi}}{E} \\
\frac{\mathbb{N}}{\pi} \\
\frac{\pi}{0}\end{array}$} & $15 \mathrm{~cm}$ & 170.82 & 212.37 & 227.84 & 227.72 & 195.72 & $206.90 \mathrm{~B}$ \\
\hline & $20 \mathrm{~cm}$ & 192.20 & 224.12 & 239.59 & 228.60 & 209.10 & $218.73 \mathrm{~A}$ \\
\hline & $25 \mathrm{~cm}$ & 194.66 & 224.97 & 237.74 & 243.65 & 220.14 & $224.23 \mathrm{~A}$ \\
\hline & Ortalama & $185.90 d$ & $220.49 \mathrm{~b}$ & $235.06 \mathrm{a}$ & $233.33 \mathrm{a}$ & $208.32 \mathrm{c}$ & \\
\hline
\end{tabular}

Sıra üzeri mesafeye göre kavuzsuz taze koçan ağılı̆̆ı 206.90-224.23 g arasında değișmiș ve en yüksek değer $25 \mathrm{~cm}$ sıra üzeri mesafede elde edilmiștir. Bitki sıkığının artması taze koçan ağırlığını azaltmıștır. Benzer sonuçlar Alıcı (2005) tarafından yapılan çalıșmada bulunmuș ve tek koçan verimi sıra üzeri mesafe arttıkça artmıștır. En yüksek değer $22 \mathrm{~cm}$, en düșük değer ise $16 \mathrm{~cm}$ sıra üzerinde belirlenmiștir.

Șeker mısırda ekim zamanı ve çeșidin, verim ve tarımsal özellikler üzerine etkisi farklı bölgelerde, değișik araștııııılar tarafından yapılan çalıșmalarla ortaya konmuștur. Ekim zamanındaki gecikmenin bitki koçan uzunluğu ve tek koçan ağırlığını arttırdığı ortaya konulmuștur (Özel ve Tansı 1994; Cesurer ve Ülger 1997).

\section{Sonuç}

Isparta koșullarında birim alandan daha fazla koçan elde etmek için Batem Tatlı șeker mısıı çeșidi Mayıs ayının ikinci haftasından Haziran ayının ilk haftasına kadar $15 \mathrm{~cm}$ sıra üzeri mesafede ekilebilir. Ekimin 15 Hazirana geciktirilmesi durumunda sıra üzeri mesafe arttırımalıdır. Nisan ayı içerisinde yapılan ekimlerin ise riskli olduğu belirlenmiștir.

Not: Bu çalıșmanın 1. yıl verileri Yüksek Lisans çalıșmasından elde edilmiștir.

\section{Kaynaklar}

Alan Ö., Sönmez K., Budak Z., Kutlu İ. ve Ayter N.G., 2011. Eskișehir ekolojik koșullarında ekim zamanının șeker mısırın (Zea mays saccharata Sturt.) verim ve tarımsal özellikleri üzerine etkisi. Selçuk Tarım ve Gıda Bilimleri Dergisi 25 (4): 3340

Alıcı S., 2005. Kahramanmaraș șartlarında farklı azot dozları ile sıra üzeri ekim mesafelerinin 2. ürün mısır (Zea mays L.) bitkisinde verim, verim unsurları ve bazı tarımsal karakterlere etkisi üzerine bir araștırma. ÇÜ. Fen Bil. Ens. Doktora Tezi, 154s

Anonim, 2015. Isparta Meteoroloji Bölge Müdürlüğü Verileri

Anonim, 2016. Isparta Meteoroloji Bölge Müdürlüğü Verileri

Atakul Ș., 2011. Diyarbakır koșullarında farklı ekim zamanlarının beș șeker mısırı (Zea mays L. saccharata Sturt.) çeșidinde taze koçan ve tane verimi ile bazı tarımsal özelliklere etkisi. ÇÜ. Fen Bil. Ens. Yüksek Lisans Tezi, 90s

Azanza F., Bar-Zur A. and Juvik J.A. 1996. Variation in sweet corn kernel characteristics associated with stand establishment and eating quality. Journal of Food Science, 61: 253-257

Cesurer L. ve Ülger A.C., 1997. Taze koçan olarak değerlendirilen șeker mısırının silajık bitki olarak üretime girmesi. Türkiye 1. Silaj Kongresi. 17-19 Eylül, Bursa, 255-260

Deng R., Wang Y., Zhen C. and Zhou Q., 2009. Effect of different sowing date on the growth and development of super sweet corn. http:// en.cnki.com.cn/Article_en/CJFDTOTALFSDX-200903003.htm 
Dickerson W.G., 1996. Home and market sweet corn production. http://aces.nmsu.edu/ pubs/_h/H223/Hanna H.Y. and Story R.N., 1992. Yield and super swet corn as affected by $\mathrm{N}$ application timing plant densty, tiller removal and insecticides. Proc. Flo. State Hort. Sci., 105, 343-344

Kahrıman F., Egesel C.Ö., Turhan H. ve Özkan P., 2007. Șeker mısırda (Zea mays saccharata Sturt.) farklı tohumluk miktarlarının koçan verimi üzerine etkisi. Türkiye VII. Tarla Bitkileri Kongresi. 25-27 Haziran, Erzurum, Cilt 1: 318-321

Kırtok Y., 1998. Mısır Üretimi ve Kullanımı. Kocaoluk Basım ve Yayınevi. 445s. İstanbul

Özel R. ve Tansı V., 1994. Çukurova koșullarında iki șeker mısır çeșidinde șașırtmanın ve farklı ekim zamanlarının verim ve diğer bazı özelliklere etkisi. Tarla Bitkileri Kongresi, E. Ü. Ziraat Fakültesi, İzmir, Türkiye, 25-29 Nisan 1994, Cilt.1, No.1, s.300-302

Park K.Y., Kang Y.K., Park S.U. and Moon H.G., 1989. Effects of planting density of tiller removal on growth and yield of sweet corn hybrids. Korean J. Crop Sci. 34:192-197

Sade B. 2002. Mısır Tarımı. Konya Ticaret Borsası. Yayın No:1, Konya

Sencar Ö., 1998. Mısır Yetiștiriciliğinde Ekim Sıklığı ve Azotun Etkileri. Cumhuriyet Üniversitesi Tokat Ziraat Fakültesi Yayınları. 6. Bilimsel Araștırmalar ve İncelemeler, Yayın No:3, Tokat
Sharma T.R. and Adamu I.M., 1984. The effects of plant population on the yield and yield attributing characters in maize (Zea mays L.). Zeitschrift fur Acker-und pflanzenbau. 153(4): 315-318. (Field Crop Absts.. 1985. 38: 3437)

Sönmez K., Alan Ö., Kınacı E., Kınacı G., Kutlu I.., Budak Bașçiftçi Z. ve Evrenosoğlu Y., 2013. Bazı șeker mısırı çeșitlerinin (Zea mays saccharata Sturt) bitki koçan ve verim özellikleri. Süleyman Demirel Üniversitesi Ziraat Fakültesi Dergisi, 4(1): $28-40$

Taș T., 2010. Harran ovası koșullarında farklı ekim sıklıklarında yetiștirilen mısırda (Zea mays L. indentata) değișik büyüme dönemlerinde yapılan hasadın silaj ve tane verimine etkisi. Ç.Ü. Fen Bil. Ens. Yüksek Lisans Tezi, 104s

Turgut İ. ve Balcı A., 2002. Bursa koșullarında değișik ekim zamanlarının șeker mısırı (Zea mays saccharata Sturt.) çeșitlerinin taze koçan verimi ile verim öğeleri üzerine etkileri. UÜ. Ziraat Fakültesi Dergisi, 16(2): 79-91

Turgut I., 2000. Bursa koșullarında yetiștirilen șeker mısırında (Zea mays saccharata Sturt.) bitki sıklığının ve azot dozlarının taze koçan verimi ile verim öğeleri üzerine etkisi. Turk J. Agric. For., 24: 341-347

Uçkesen B., 2000. Tekirdağ koșullarında I. ürün ve II. ürün olarak șeker mısır (Zea mays saccharata Sturt.) yetiștirme olanaklarının belirlenmesi. T.Ü. Fen Bil. Ens. Yüksek Lisans Tezi, 76s 